\title{
Structure of the crust and uppermost mantle beneath the Sicily Channel from ambient noise and earthquake tomography
}

\author{
Radia Kherchouche*,1,2,3, Merzouk Ouyed ${ }^{1}$, Abdelkrim Aoudia ${ }^{3}$, Billel Melouk ${ }^{2}$, \\ Ahmed Saadi ${ }^{2}$ \\ (1) Laboratoire de Géophysique, Faculté des Sciences de la Terre, de la Géographie et de l'Aménagement du territoire, \\ USTHB, B.P. 32 El Alia, 16111 Bab Ezzouar Alger, Algeria. (http://www.usthb.dz) \\ (2) Centre de Recherche en Astronomie, Astrophysique et Géophysique, BP. 63, Bouzaréah, 16340, Algiers, Algeria. \\ (https://www.craag.dz) \\ (3) The Abdus Salam International Centre for Theoretical Physics, Earth System Physics Section, Strada Costiera 11, \\ 34014, Trieste, Italy. (https://www.ictp.it)
}

Article history: received September 6, 2019; accepted September 16, 2020

\begin{abstract}
In this work, we study the crust and the uppermost mantle structure beneath the Sicily Channel, by applying the ambient noise and earthquake tomography method. After computing cross-correlation of the continuous ambient noise signals and processing the earthquake data, we extracted 104 group velocity and 68 phase velocity dispersion curves corresponding to the fundamental mode of the Rayleigh waves. We computed the average velocity of those dispersion curves to obtain tomographic maps at periods ranging from $5 \mathrm{~s}$ to $40 \mathrm{~s}$ for the group velocities and from $10 \mathrm{~s}$ to $70 \mathrm{~s}$ for the phase velocities. We inverted group and phase speeds to get the shear-wave velocity structure from the surface down to $100 \mathrm{~km}$ depth with a lateral resolution of about $200 \mathrm{~km}$. The resulted velocity models reveal a thin crust with thickness value of $15 \mathrm{~km}$ beneath the southern part of the Tyrrhenian basin and a thickness value of $20 \mathrm{~km}$ beneath Mount Etna. The obtained thickness values are well correlated with the reported extension of the Tyrrhenian lithosphere due to the past subduction and rollback of the Ionian slab beneath the Calabrian Arc. The crustal thickness increases and reaches values between 28 and $30 \mathrm{~km}$ beneath the Tunisian coasts and Sicily Channel. The S-wave models reveal also the presence of high velocity body beneath the island of Sicily. This finding can be interpreted as the presence of the Ionian slab subducting beneath the Calabrian Arc. Another high velocity body is observed beneath the southern part of the Tyrrhenian basin, it might be interpreted as the presence of fragments of the African continental lithosphere beneath the Tyrrhenian basin.
\end{abstract}

Keywords: Sicily Channel; Seismological data; Data processing; Tomography; Inverse methods.

\section{Introduction}

The Sicily Channel, located between northern Africa and Sicily, represents the eastern part of the foreland Maghrebides-Apennines thrust belt that connects the African and the Eurasian plates (red rectangle in Figure 1). 


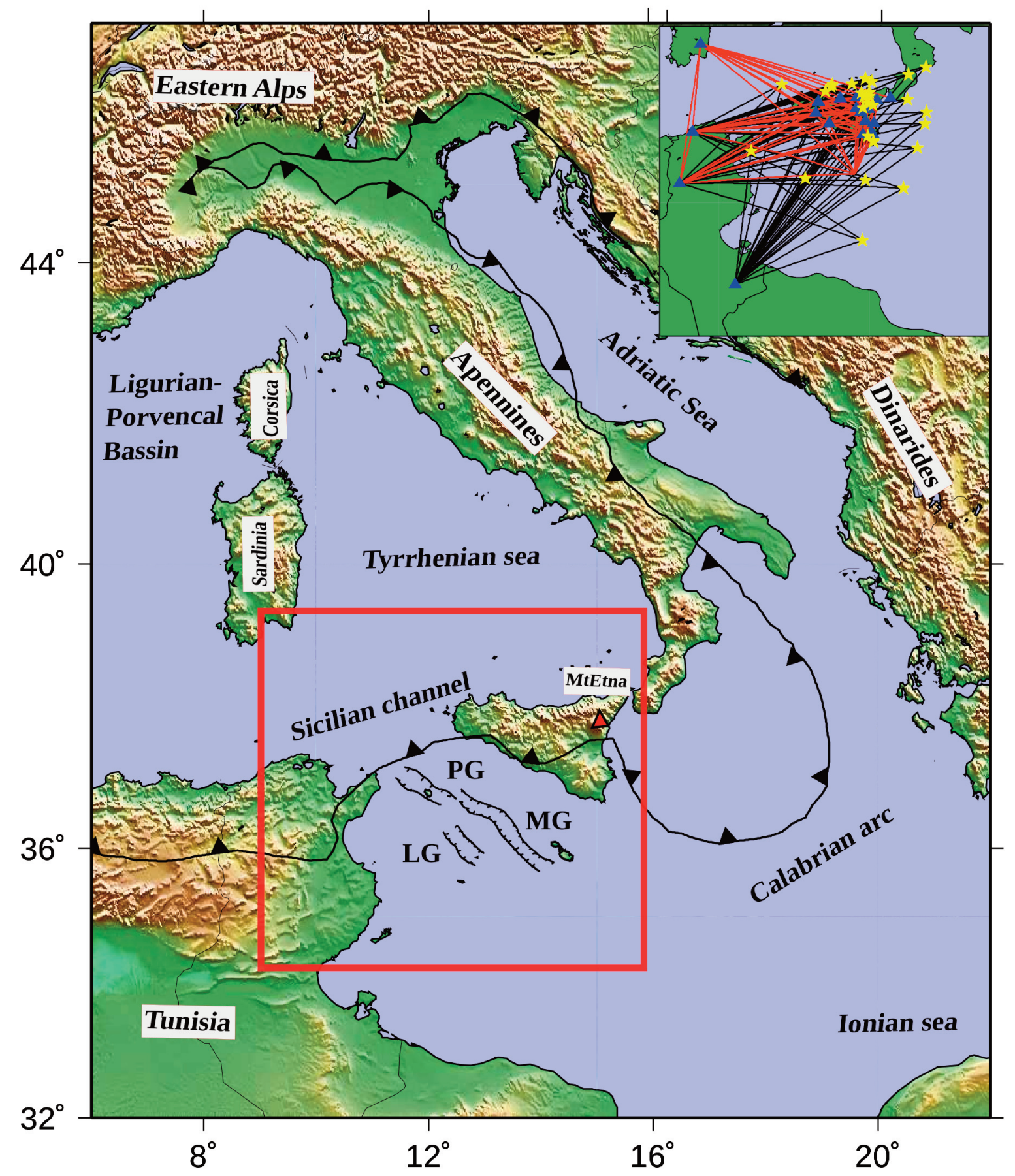

Figure 1. Tectonic setting map of the eastern Mediterranean basins. The topographic elevations are taken from the ETOPO1 Global Relief Model with a resolution of one arc-minute (https://www.ngdc.noaa.gov). The thick black lines represent the major orogenic fronts. The thin segments indicate the extensional structures and the resulted grabens: PG: Pantelleria graben, MG: Malta graben, LG: Linosa graben. The red rectangle represents the focused area. The black segment inside the red rectangle is for the Maghrebides-Sicily-Apennines fold-thrust belt. The map on the top right shows the ray coverage of the study area. The blue triangles show the location of seismic stations. Yellow stars indicate the earthquakes location used in our work. Red segments represent the rays obtained from ambient noise data while the black segments are for the rays obtained from earthquake data. 
This area is characterised by two principal tectonic regimes: A northeast-southwest extension due to the Sicily Channel rift, overlapping the northwest-southeast compression due to the Maghrebides-Sicily-Apennines accretionary prism [e.g. Corti et al., 2006]. During the Neogene-Quaternary, the channel has been affected by a process of continental rifting which produced two principal geologic features: the Pantelleria, Malta and Linosa tectonic depressions, and the thinning of the crust that can reach $17 \mathrm{~km}$ beneath the Pantelleria graben [Civile et al., 2008, 2010; Coltelli et al., 2016; Biolchi et al., 2011; Lodolo et al., 2012]. Submerged by sea water, the Sicily Channel is showing bathymetric depths less than $400 \mathrm{~m}$ in the most of the area, while it reaches depth ranging from $1300 \mathrm{~m}$ to $1700 \mathrm{~m}$ beneath the Pantelleria, Malta and Linosa islands. Those depressions are likely related to the NW-trending rift system crosscutting the Apennines-Maghrebides belt [Calò and Parisi, 2014; Civile et al., 2015; Bonaccorso and Mattia, 2000]. Some authors related the rifting process to the northeastward motion of Sicily away from Africa [Palano et al., 2012; Civile et al., 2008] while Argnani [1990] interpreted this process as caused by lateral mantle convection developed during the roll-back of the African lithosphere slab beneath the Tyrrhenian basin. Recent studies reported that the shortening and rifting processes related to the Sicily Channel are still active [e.g. Catalano et al., 2009; D’Agostino and Selvaggi, 2004; Serpelloni et al., 2007 and Devoti et al., 2011]. From Geodetic data, the GPS stations installed in Lampedusa and Sicily showed velocities of $1.5 \pm 0.5 \mathrm{~mm} /$ year indicating a NE-SW oriented extension [Serpelloni et al., 2007]. In the outer part of the Apennines-Sicily-Maghrebides belt, Devoti et al. [2011] reported a contraction motion velocity of $1.1 \pm 0.2 \mathrm{~mm} /$ year that accommodates the Africa-Eurasia convergence.

Seismicity studies in the Sicily Channel are very few, because of limited station coverage on the North African side and the lack of OBS (Ocean Bottom Seismometer) stations. Some results were reported in the Sicily Channel by Calò and Parisi [2014], Spampinato et al. [2017], Panzera et al. [2015] and Neri et al. [2018]. Spampinato et al. [2017] and Agius and Galea [2011] reported the presence, in the central part of the Sicily Channel, of a dense cloud of small to moderate crustal seismic events oriented nearly NS, which, together with the distribution of the main volcanic centers, support the existence of a fault zone crossing the sea from Sciacca to Linosa islands. Calò and Parisi [2014] associated this seismicity with the normal faulting related to the rifting process and volcanic activity of the region. From fault plane mechanisms available in the Sicily Channel and Southern Sicily, Neri et al. [2018] reported solutions that are compatible with a NW-SE compression from plate convergence in the eastern part of the study area, and the presence of some SW-NE extensional process acting together with a NW trending plate convergence.

Trying to explain the origin of the seismic activity in the Sicily Channel and surrounding area, many authors attempted to image the structure of the crust and upper mantle beneath the Mediterranean basin. Wortel and Spakman [2000] considered the Sicily Channel as a dextral transform plate boundary that cannot be a subduction zone. The P wave tomographic maps proposed by Bijwaar and Spakman [2000] and imaging the Mediterranean basin indicated the absence of the subducted lithosphere underneath this boundary segment. This inference is in concordance with the shallow seismicity in the region. For deeper structures Spakman and Wortel [2004] and Piromallo and Morelli [2003] presented tomographic maps that reveal a low P wave velocities at depths of 150 to 200 $\mathrm{km}$ beneath the Sicily Channel. These low velocities mark the rifting process occurring in the region. The geodynamics in the Mediterranean basin is very complex and is still debated. High resolution tomographic maps imaging the crust and upper mantle structures of the Mediterranean basin and Sicily Channel are lacking due to the limited number of available seismic stations.

To image the crust and the uppermost mantle beneath the Sicily Channel, we used the ambient noise tomography method combined with earthquake based surface wave tomography data. We estimated 68 empirical Green functions by cross-correlating and summing 4 years of continuous seismic ambient noise recorded between each pair of 19 broadband stations. To increase the number of rays crossing the area, we used 87 earthquake signals occurred in Sicily from 02-04-2010 to 03-12-2016 and recorded on the vertical component of the TAMR, TATN, and THTN Tunisian broadband stations. To measure the dispersion characteristics of Rayleigh waves, we applied a multiple filter analysis on the ambient noise cross-correlations and earthquake signals. We then extracted 104 group velocity and 86 phase velocity dispersion curves corresponding to the fundamental mode of the Rayleigh waves. We calculated the average velocity of those dispersion curves using a $0.5^{\circ} \times 0.5^{\circ}$ grid, to obtain tomographic maps at periods ranging from $5 \mathrm{~s}$ to $40 \mathrm{~s}$ for the group velocities and from $10 \mathrm{~s}$ to $70 \mathrm{~s}$ for the phase velocities. Using group and phase speeds, we inverted each node of the grid using a linear method to get the shear-wave velocity structure from the surface down to $100 \mathrm{~km}$ depth with a lateral resolution of about $200 \mathrm{~km}$. Some vertical sections crossing the area under study were mapped to show the velocity with depth representing the crust and upper mantle structure beneath the Sicily Channel. 


\section{Radia Kherchouche et al.}

\section{Data and methods}

The seismic ambient noise is defined as the constant vibrations of the Earth's surface at different seismic frequencies, even without earthquakes [Okada, 2003]. The seismic ambient noise tomography is considered as a passive tomographic method to image the Earth interior. Bensen et al. [2007], Shapiro et al. [2004, 2005] and Stehly et al. [2006, 2008] showed that the cross-correlation of the permanent ground vibrations computed between a pair of receivers will result in a waveform that differs only by an amplitude factor from the Green function computed between the two receivers.

To study the velocity structure of the lithosphere and uppermost mantle beneath the Sicily Channel, we collected continuous recordings of ambient noise from 19 broad-band vertical-component stations within a time period of four years (01-01-2010 to 31-12-2013). Due to the limited number of available broadband Tunisian stations and to increase the number of rays crossing the area, we analysed 87 earthquake signals recorded at the Tunisian stations TAMR, TATN, and THTN, for a time period ranging from 02-04-2010 to 03-12-2016. The continuous recordings and earthquake signals were downloaded from different networks: Tunisia Broad Band network (TT), Italian seismic network (IV) (INGV Seismological Data Centre, [2006]) and Mediterranean very broadband seismographic network (MN) (MedNet Project Partner Institutions, [1990]), using the European Integrated Data Archive EIDA (http://www.orfeuseu.org/eida/eida.html). Map on the top right of Figure 1 shows the ray coverage of the study area.

To determine the surface wave dispersion of the Rayleigh waves fundamental mode from ambient noise data, we follow the processing data methodology proposed by Bensen et al. [2007]. For each continuous recording we (i) cut daily signals (ii) remove instrumental response that can obscure the ambient noise (iii) remove mean and trend (iv) apply a band-pass filter between 0.006 and $0.2 \mathrm{~Hz}(v)$ decimate the daily signal to 1 sample per second ( $v i$ ) apply a time domain normalisation to reduce the effect of earthquakes on the cross-correlations, instrumental irregularities and nonstationary noise sources near each station (vii) apply a frequency domain by adding white noise to the data. We use the processed daily signals to compute the cross-correlation between each pair of stations and then we stack all the resulting daily cross-correlations to a single time-series to increase the Signal to Noise Ratio SNR. 68 cross-correlation signals with SNR greater or equal to 7 were retained. The retained signals are represented by red segments in the map on the top right of Figure 1. The processing and the computation of cross-correlations were done using the Seismic Analysis Code of Goldstein et al. [2003]. Figure 2b shows an example of positive and negative lags of the stacked cross-correlation between the two stations THTN and WDD depicted in Figure 2a, while Figure 2c shows the average signal obtained after summing the positive and negative lags. Figures $2 \mathrm{~d}$ and $2 \mathrm{e}$ represent the group and phase velocity dispersion curves (red curves), respectively, that correspond to the Rayleigh waves extracted from the stacked cross-correlation signal. The dispersion curves are compared to two global models: Preliminary Reference Earth Model (PREM) developed by Dziewonski and Anderson [1981] (black dashed curve) and Global Dispersion Model (GDM52) (blue dashed curve) of Ekström [2011].

To increase the ray coverage, we used 87 earthquake signals occurred in Sicily from 02-04-2010 to 03-12-2016 and recorded on the vertical component of the Tunisian broadband stations: TAMR, TATN, and THTN. We selected 72 earthquakes with magnitudes greater than 4 and hypocentral distance greater than $100 \mathrm{~km}$. The earthquake signals were processed by applying the same methodology from step ii) to $v$ ). The seismic travel times were automatically calculated using the automatic seismic travel time calculator TauP Toolkit [Crotwell et al., 1999].

To measure the dispersion characteristics of the fundamental mode of the Rayleigh waves from the ambient noise cross-correlations and earthquake signals, we apply a multiple filter analysis using the program Do_mft from Herman package [Herman, 2013]. We extracted 104 group velocity and 86 phase velocity dispersion curves. Figure 3 shows the example of group and phase velocity dispersion curves extracted from the cross-correlation of the ambient noise of 6 different station pairs.

To calculate the average speed of Rayleigh group and phase velocity dispersion curves at different periods on a $0.5^{\circ}$ by $0.5^{\circ}$ grid, we used the 2D tomography method of Ditmar and Yanovskaya [1987]. This method based on a generalisation to 2D of the 1D approach of Backus and Gilbert (1968), it has been widely used in surface waves tomography studies [Ritzwoller et al., 1998; Vuan et al., 2005; Guidarelly et al., 2011 and Manu-Marfo et al., 2019]. It can also estimate the resolving power of the data by using a functional $s(x, y)$ for different orientations of the coordinate system to determine the sizes of the averaging area along different directions, for each point (x,y) of the grid. The resolution can be approximated over the parameter $L=\left(S_{\min }+S_{\max }\right) / 2$, where $S_{\min }$ and $S_{\max }$ are values of $\mathrm{s}(\mathrm{x}, \mathrm{y})$, corresponding respectively to the largest and smallest axis values of an ellipse centred at that point [Yanovskaya et al., 1997]. The maximum period of each Rayleigh group velocity dispersion curve was fixed following 
Velocity structure of the Sicily Channel
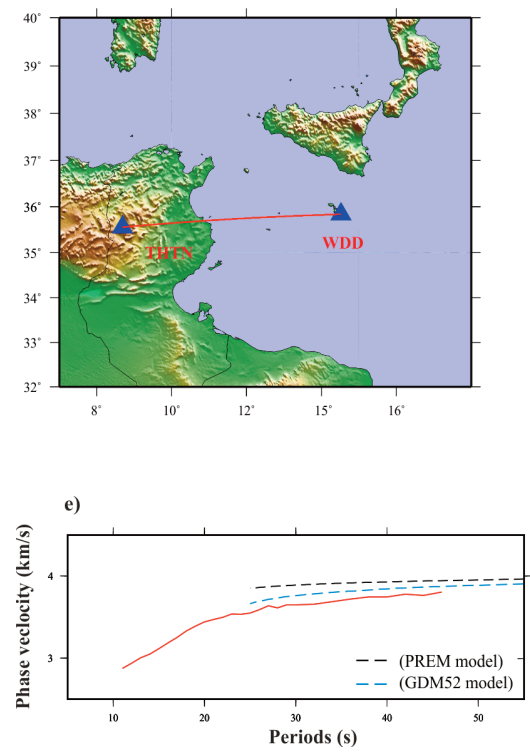

b)
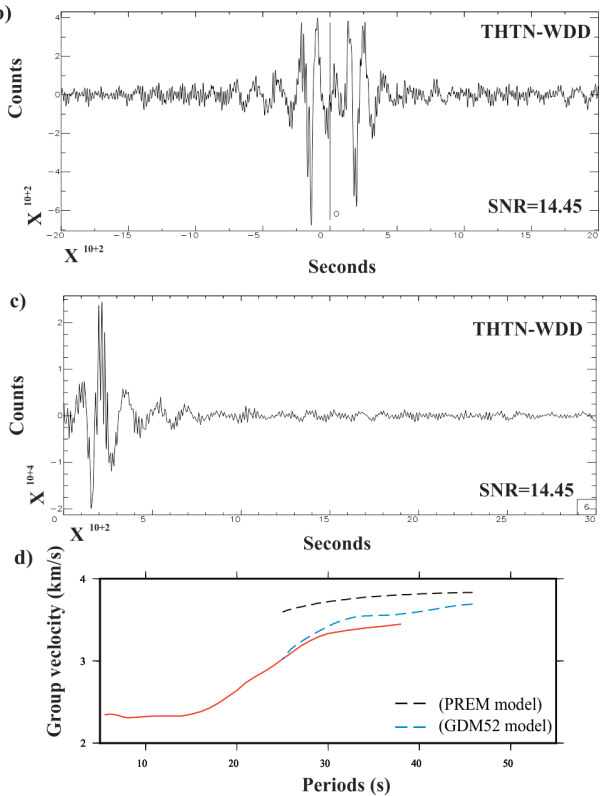

Figure 2. a) Map showing the location of the stations THTN and WDD (blue triangles). b) Shows the stacked crosscorrelation with the positive and negative lags, the SNR of the signal is mentioned in the bottom right of the signal window. The signal has been bandpass filtered between 0.006 and $0.02 \mathrm{~Hz}$ c) Shows the average stacked cross-correlation signal, the SNR of the signal is mentioned in the bottom right of the signal window. d) The red curve shows the Rayleigh-wave group velocity dispersion curve picked using our data. The black and blue dashed curves represent the group velocity dispersion obtained from a global PREM model and a global GDM52 model, respectively. e) The red curve shows the Rayleigh-wave phase velocity dispersion picked using our data. The black and blue dashed curves are for the phase velocity dispersion obtained from the PREM and GDM52 models, respectively. The two models are well described in Ekström (2011).

a)

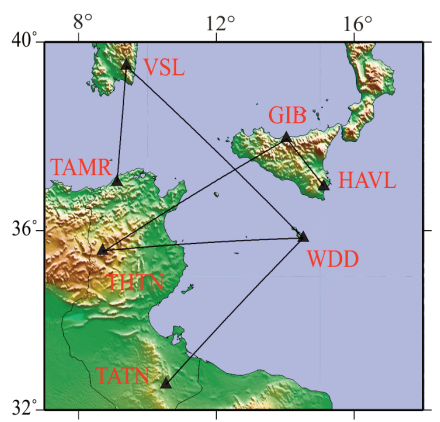

b)

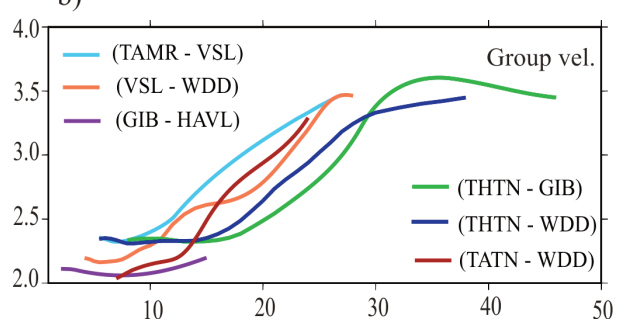

c)

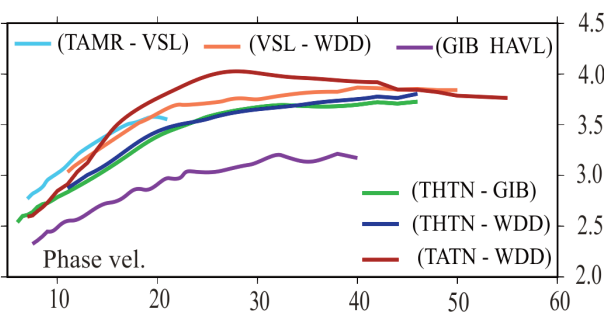

Figure 3. a) Map showing the location of the stations (in black triangles) and the rays obtained from ambient noise data (black segments).b) and c) Show different Rayleigh-wave group and phase velocity dispersion curves respectively, measured from the cross-correlation of seismic ambient noise for the different station pairs shown in the map a). 


\section{Radia Kherchouche et al.}

the criterion of Bensen et al. [2007], where the maximum period $\tau$ requires an inter-station distance $\Delta$ greater than three wavelengths $\lambda ;\left(\Delta>3^{*} \lambda=3^{*} \mathrm{c}^{*} \tau\right.$; where $\mathrm{c}$ is the Rayleigh group velocity). For each Rayleigh phase velocity dispersion curve, the maximum period was fixed following the study of Luo et al. [2015], where they demonstrated that Rayleighwave phase velocity dispersion measurements at short inter-station distances $\Delta$ as short as one wavelength are consistent and reliable as those at distance longer than three wavelengths.

\subsection{Group velocity tomographic maps}

Applying the method described above on our group velocity dispersion data, we get a spatial resolution of 180 $\mathrm{km}$ for periods from $5 \mathrm{~s}$ to $30 \mathrm{~s}$. Figure 4 shows the resulting Rayleigh group velocity tomographic maps. The group velocity maps at shorter periods ( $5 \mathrm{~s}$ and $10 \mathrm{~s}$ ) represent the sensitivity of the surface waves to shallow structures. The main features shown by those maps are the negative anomalies in the southern part of Sicily and in the eastern part of the Tunisian margins likely related to the presence of sediments in those areas. At periods 15, 20 and $25 \mathrm{~s}$, the tomographic maps reveal a sharp contrast in group velocities which reflect the increase in the crustal thickness from the south of the Tyrrhenian basin to the south of the Sicily Channel. The tomographic maps show also the presence of high velocity materials at shallow depths. The extent of low velocity anomaly detected in the south of Sicily, the Sicily Channel and the east of the Tunisian margins reflects regions with deeper values of the Moho (crust-mantle boundary). At longer periods $30 \mathrm{~s}$ and $40 \mathrm{~s}$, the sensitivity of surface waves is influenced by deeper structures and it is well correlated with the crust-mantle boundary. Low velocity anomalies indicate regions with deep Moho, while higher velocities correspond to regions with shallow Moho.

\subsection{Phase velocity tomographic maps}

Using the same tomographic method on our Rayleigh phase velocity dispersion data, we get a spatial resolution of $160 \mathrm{~km}$ for period $10 \mathrm{~s}, 180 \mathrm{~km}$ for periods 20 and $30 \mathrm{~s}$ and $250 \mathrm{~km}$ for periods 40,50 , and $60 \mathrm{~s}$. Figure 5 shows the resulting Rayleigh phase velocity tomographic maps. The maps at periods 10 and $20 \mathrm{~s}$ are comparable to the respective group velocity ones. At longer periods between 30 and $60 \mathrm{~s}$, the phase velocities are mapping the uppermost mantle materials beneath the study area, they are sensitive to velocity changes from 50 to $100 \mathrm{~km}$ depth. The velocity contrast is well correlated with the crust thickness. Negative velocity anomalies represent regions with thicker crust, while positive anomalies correspond to regions with thinner crust. The results are well correlated with crustal thickness values reported by Argnani [1990] and Marone et al. [2003].

The maps depicted in Figure 6a-f and 6g-l show the lateral resolution in $\mathrm{km}$ of the Rayleigh-wave group velocity and phase velocity, respectively, at each indicated period.

\section{Shear wave velocity model}

Analysing and plotting group and phase velocity derivatives with respect to elastic parameters versus depth, we found that group velocity periods are sensitive to S-wave velocity structure in the depth range approximately between 1 and $60 \mathrm{~km}$, while the phase velocity periods are sensitive to S-wave velocity structure depth down to $100 \mathrm{~km}$ (see Figure 7).

To determine the shear wave velocity structure of the study area, we inverted simultaneously group and phase velocities, computed on each cell of the $0.5^{\circ}$ by $0.5^{\circ}$ grid used for the tomographic study. The method used for the inversion is the iterative linearized damped least-squares method proposed by Herman (2013). As the linear inversion results are dependent on the initial models, we need to choose reliable shear wave velocity $\mathrm{V}_{\mathrm{S}}$ starting models. For our study, we used 20 Vs models determined by Manu-Marfo et al. (2019) for different regions: the southern part of the island of Sicily, the northern part of the Sicily Channel and the Tunisian margins. P-wave velocities were computed using the relation between $V_{s}$ and $V_{p}:[V p / V s=\sqrt{3}]$ and the density was calculated from $V_{p}$ values using the Nafe-Drake relationship (Ludwig et al., 1970). To avoid the dependence on the initial models, we invert for each node of our grid, 20 different starting models using 5 different damping factors, letting the program repeat the inversion for 30 iterations. 

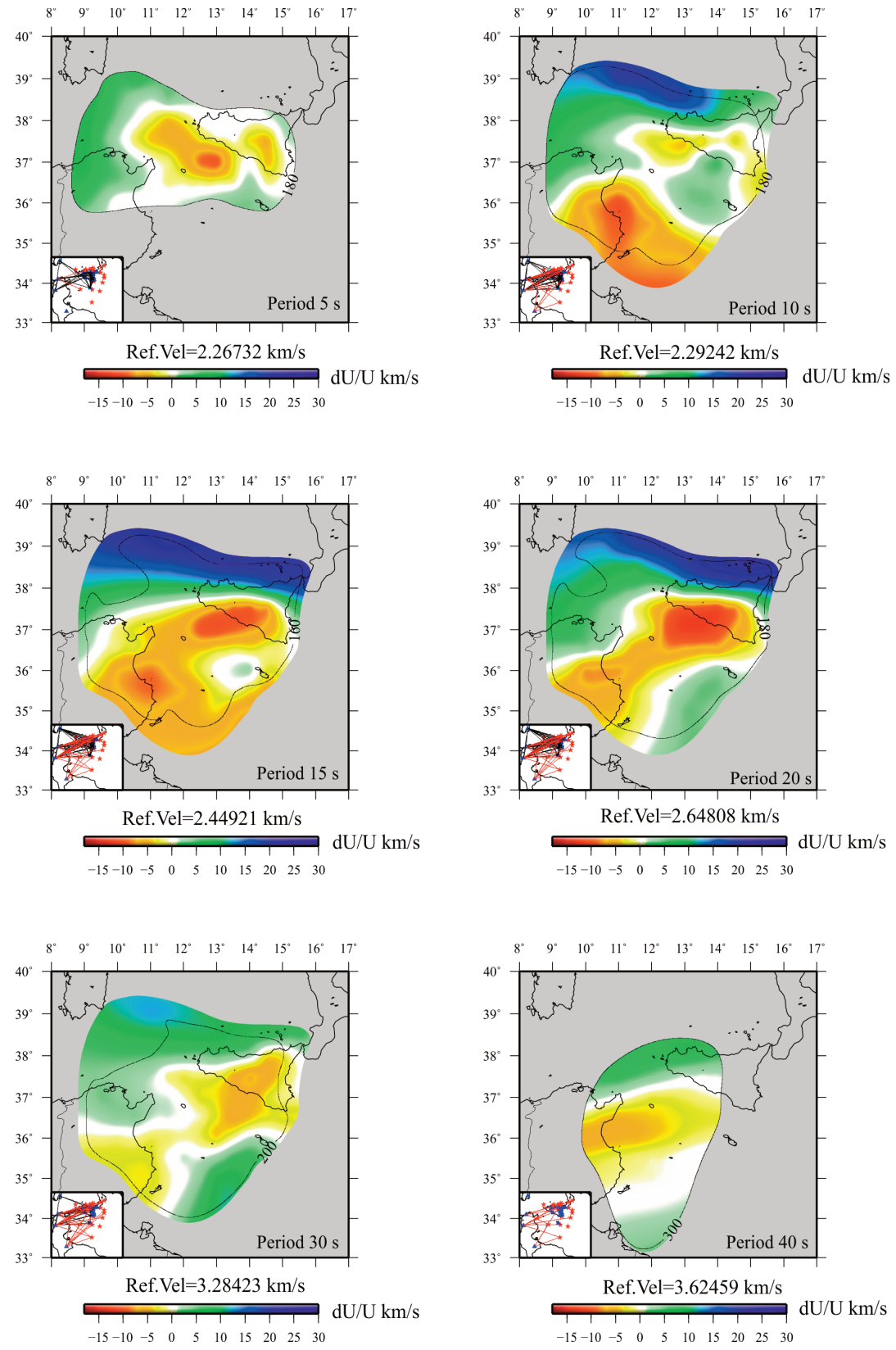

Figure 4. Group velocity tomography maps at indicated periods shown as percent deviation from the average velocity (Ref.Vel). The area in grey is with resolution length greater than $300 \mathrm{~km}$. The black contour indicates the spatial resolution lengths in $\mathrm{km}$. The map in the bottom left corner of each map indicates the ray coverage corresponding to each period.

The starting models were parametrised as a stack of 1, 1, 24, 5 and 2 layers of 1, 2, 2.5, 5 and $10 \mathrm{~km}$ thick respectively and overlying a halfspace, in which the shear wave velocity was allowed to vary. The damping factor is the parameter used to find the best trade-off between the dispersion data misfit and the shear wave velocity model roughness. To choose the proper damping factors we follow the L-curve method [Hansen, 1992; 1998], we retained the values of $0.01,0.05,0.5,1$ and 2.5. (see supplementary Figure S4). Due to the non-uniqueness of the solution, we obtained for each node of our grid 100 slightly different shear wave velocity models, the final solution is calculated as an average of all resulted models.

Analysing the resulted 1D shear wave velocity models, we determine the Moho depth value for each cell of the $0.5^{\circ}$ by $0.5^{\circ}$ using a velocity contour of $4.0 \mathrm{~km} / \mathrm{s}$ as proxy. We interpolated the Moho depth values of each cell to get 


\section{Radia Kherchouche et al.}
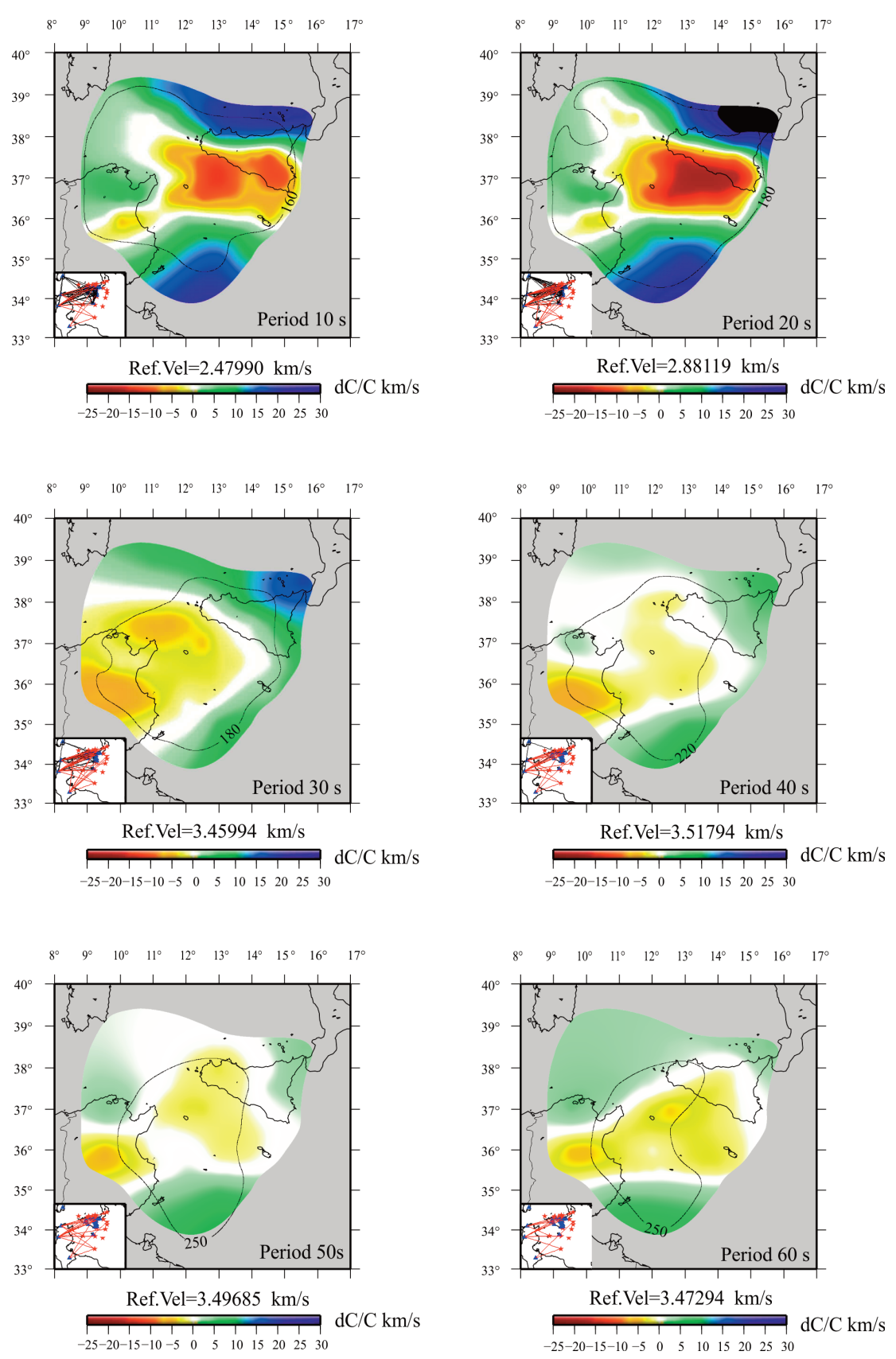

Figure 5. Phase velocity tomography maps at indicated periods shown as percent deviation from the average velocity (Ref.Vel). The area in grey is with resolution length greater than $300 \mathrm{~km}$. The black contour indicates the spatial resolution lengths in $\mathrm{km}$. The insets show the ray coverage for each period.

the 2D map representing the Moho topography beneath our study area (see Figure 8). Figure 8 reveals a shallow Moho with depth value of $15 \mathrm{~km}$ in the southern part of the Tyrrhenian basin, the depth value increases and reaches a value of $28 \mathrm{~km}$ beneath the north-western part of Sicily and the north-eastern part of the Tunisian margins. Moho depth value of $30 \mathrm{~km}$ is depicted in Figure 8 in the southern part of the island of Sicily and in the south-eastern part of the Tunisian margins. Important feature is revealed in the Moho map by the difference in crustal thickness between the northern and southern part of the Sicily Channel. We observe thickness value of $32 \mathrm{~km}$ in the northern part of the channel, while it reaches a value of $24 \mathrm{~km}$ in the southern part.

Using the final models resulting from the inversion, we plot horizontal maps of shear wave velocity model at different depths (Figure 9). The maps at 10, 20 and $30 \mathrm{~km}$ depth present low velocities (Vs between 2.5 and $3.0 \mathrm{~km} / \mathrm{s}$ ) 


\section{Velocity structure of the Sicily Channel}

in this eastern part of the Tunisian margins and the southern part of Sicily, this is well correlated with the low velocity anomalies revealed by the Rayleigh group velocity tomographic maps at periods of 5 and $10 \mathrm{~s}$, which is interpreted as the presence of sediments in those areas. Other important feature is represented in the maps at 40, 50 and $60 \mathrm{~km}$ depth, by the presence of high velocity body (Vs between 4.5 and $4.8 \mathrm{~km} / \mathrm{s}$ ) in the eastern part of the island of Sicily, the southern part of the Tyrrhenian basin and the northern and central part of the Sicily Channel.

The final models resulting from the inversion method are plotted on 8 vertical sections representing the shear wave velocity structure of the crust and the uppermost mantle beneath the Sicily Channel. Figure 10 shows the obtained vertical cross-sections. Sections A, B, C, and D are crossing the Sicily Channel from northeast to southwest. Sections E, F, and G are crossing the study area from the northwest to southeast. The cross-section $\mathrm{H}$ is along the $37^{\circ}$ parallel (see the map in the bottom left of Figure 10). We plot also the seismic events from the catalog published by Chiarabba et al. [2015] obtained after refining hypocentral earthquakes that occurred in the central Mediterranean region for the time period between 2005 and 2012 (Figure 10).
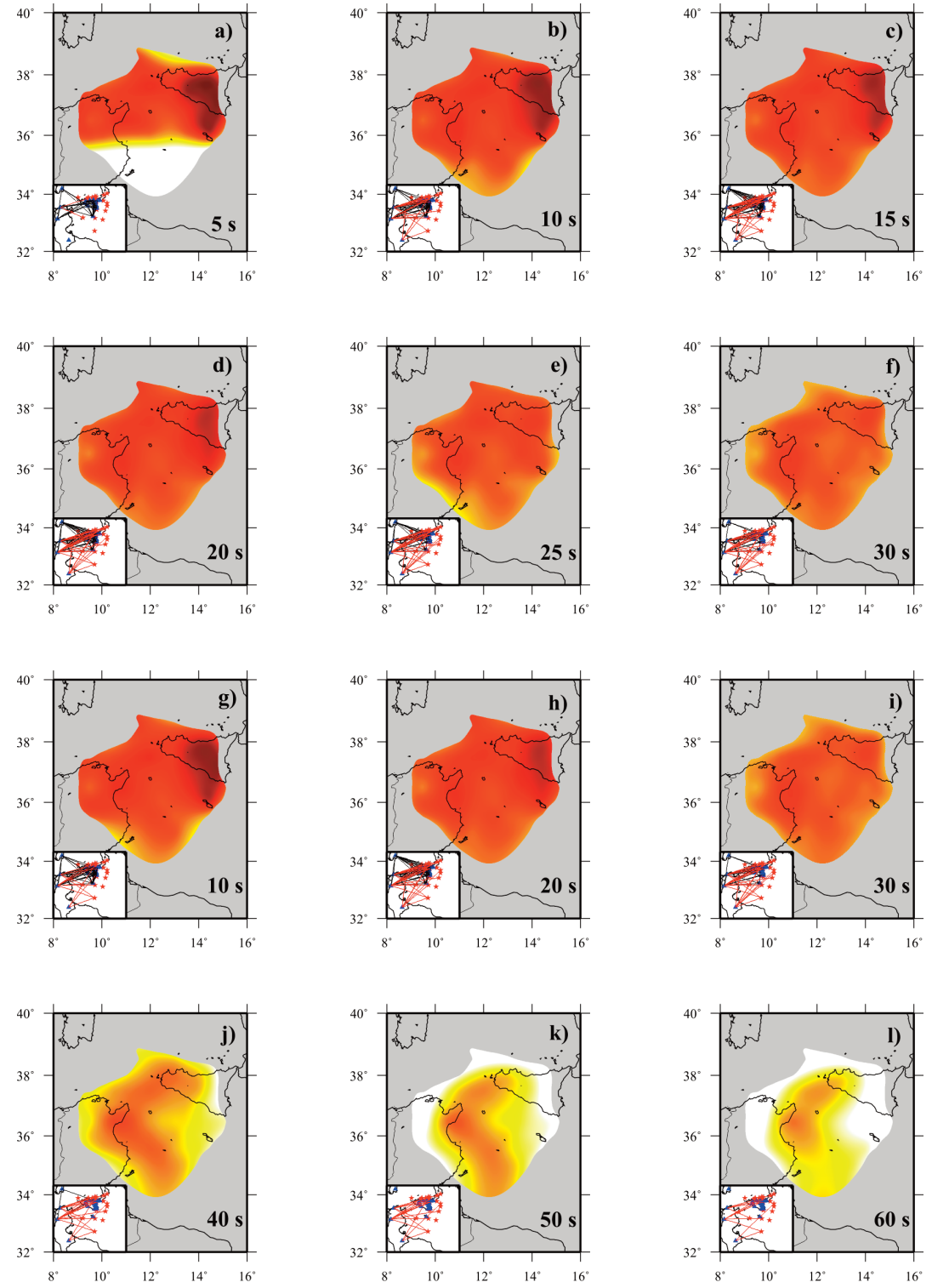

$\begin{array}{llllll}50 & 100 & 150 & 200 & 250 & 300\end{array}$

Resolution (Km)

Figure 6. Lateral resolution in $\mathrm{km}$ of the tomographic maps at indicated periods. Maps 6a-f correspond to the Rayleighwave group velocity. Maps $6 \mathrm{~g}-1$ are for the Rayleigh-wave phase velocity. 
Radia Kherchouche et al.

dU/db

dC/db
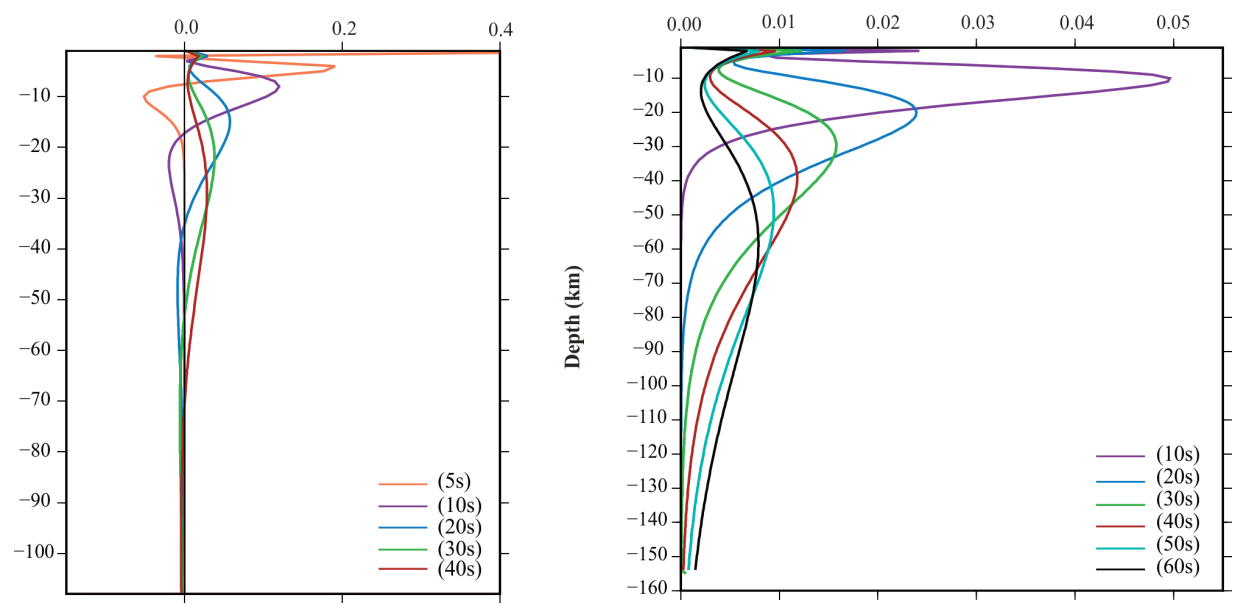

Figure 7. Sensitivity kernels of the Rayleigh-wave group velocity (on the left) and of phase velocity (on the right). The different periods are indicated with different colors in the bottom right of each plot.

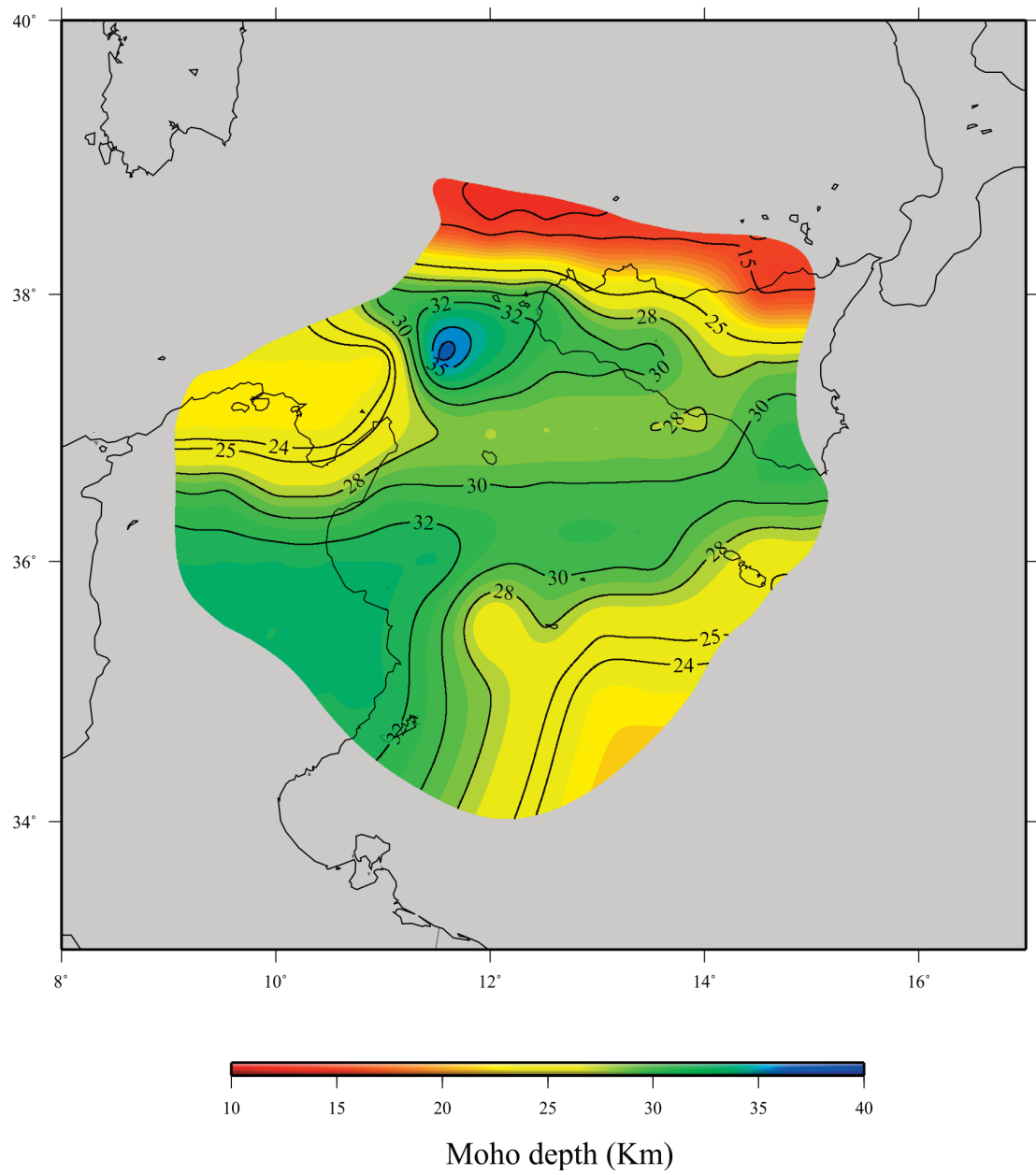

Figure 8. Moho depth map. The black contours show in km the different Moho depth values beneath our study area. The area in grey is with spatial resolution length greater than $300 \mathrm{~km}$. 

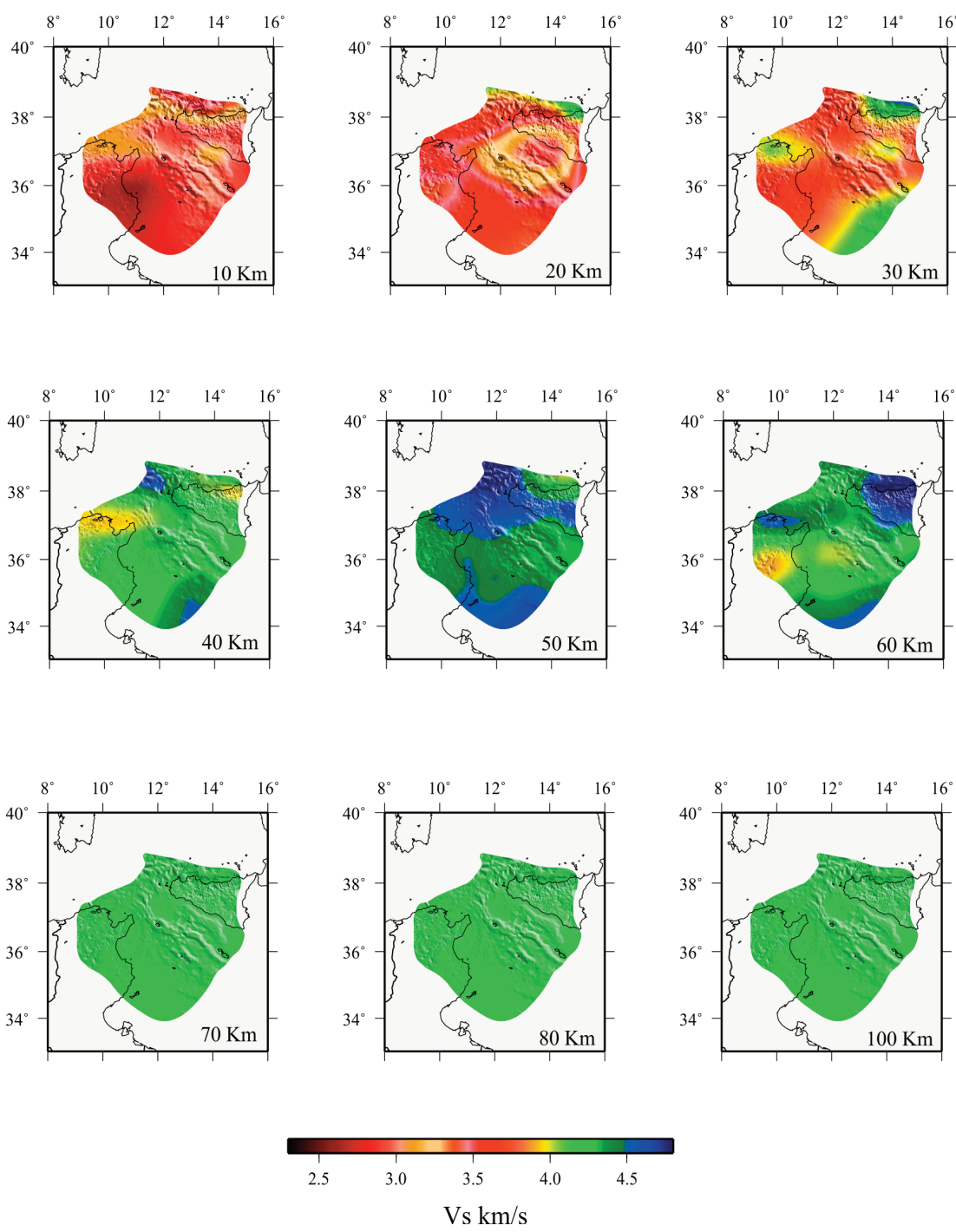

Figure 9. Shear velocity model at different depths beneath the Sicily Channel. The area in light grey is with spatial resolution length greater than $300 \mathrm{~km}$.

Section A is crossing the southern part of the Sicily Channel. This section shows an upper crust thickness of 20 to $25 \mathrm{~km}$ with shear wave velocity between $2.3 \mathrm{~km} / \mathrm{s}$ and $3.3 \mathrm{~km} / \mathrm{s}$ where much of the seismicity is located over a faster lower crust with Vs up to $3.9 \mathrm{~km} / \mathrm{s}$. The Moho is likely at depth of about $38 \mathrm{~km}$ beneath the southeast of the island of Sicily, it decreases and reaches a value of $30 \mathrm{~km}$ beneath the Sicily Channel. Section B starts from the Northeast of the island of Sicily, at Mt. Etna and reaches the Tunisian coast. This section shows crustal thickness values of $18 \mathrm{~km}$ beneath the Etna complex and around $30 \mathrm{~km}$ beneath the Sicily Channel and the Tunisian coast. The section shows also the presence of a high velocity body at depths from 20 to $40 \mathrm{~km}$ and from 55 to $70 \mathrm{~km}$ with shear wave velocities between $4.5 \mathrm{~km} / \mathrm{s}$ and $4.8 \mathrm{~km} / \mathrm{s}$. The seismicity plotted on this section is showing a dense shallow activity beneath the Mt. Etna volcano and some events beneath the Malta and Linosa grabens where the crust is likely exhibiting its maximum thickness. The section C is parallel to section B but further north going through the Island of Pantelleria where like Malta and Linosa the crust exhibits an average thickness of $28 \mathrm{~km}$. This section reveals also the existence of a mantle velocity between 3.7 and $4.0 \mathrm{~km} / \mathrm{s}$, at depth between 15 and $20 \mathrm{~km}$, beneath the south-eastern part of the Tyrrhenian basin and lies at depth between 30 and $40 \mathrm{~km}$ beneath the central part of the Sicily Channel. The seismicity plotted on this section shows a high activity beneath the Aeolian islands, with some deep events beneath the northeast of Sicily reaching depth of $80 \mathrm{~km}$. Section D is running from the South of the Tyrrhenian basin to the North of the Tunisian coast. This section is showing a very thin crust with thickness 


\section{Radia Kherchouche et al.}
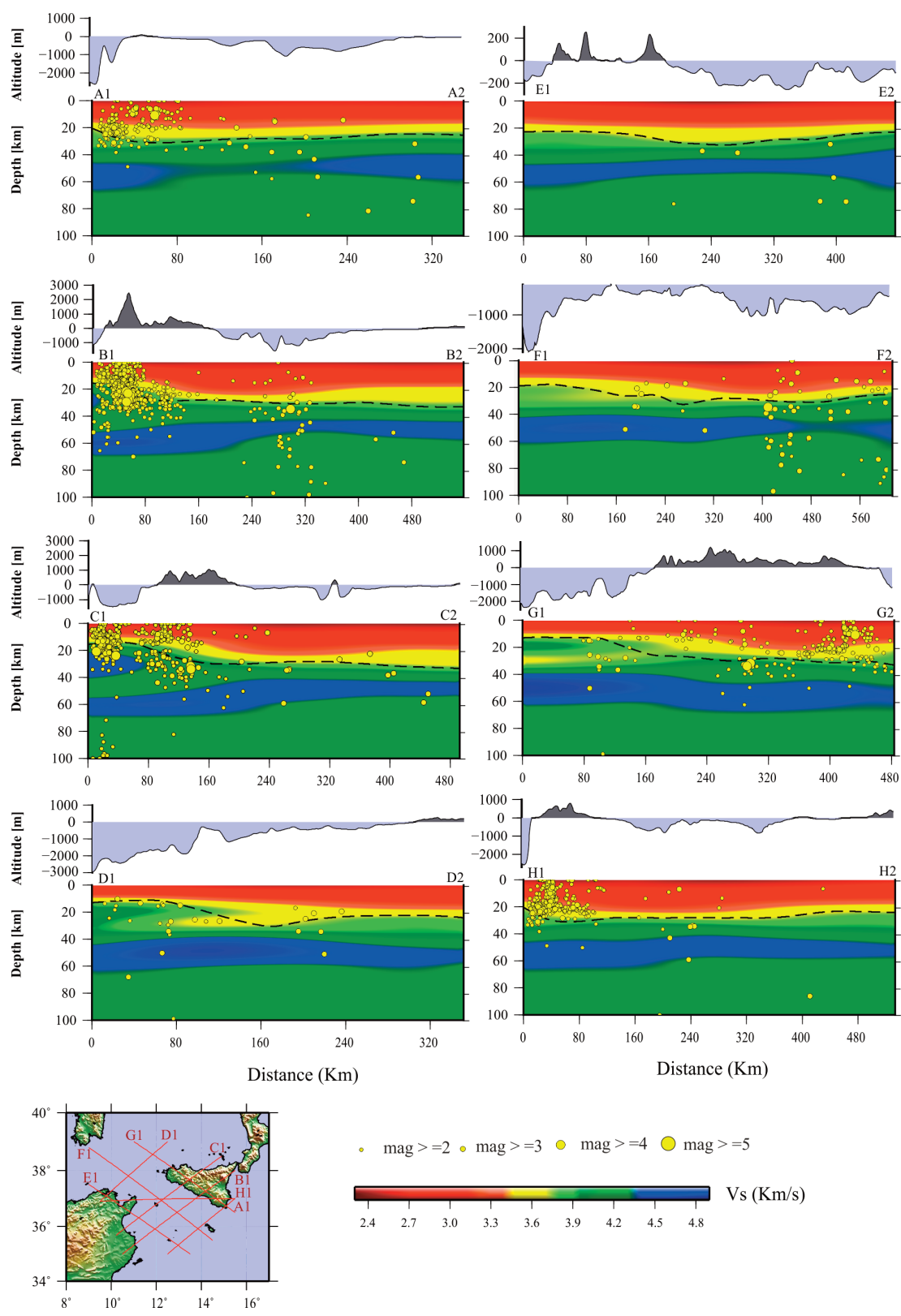

- $\operatorname{mag}>=2 \circ \operatorname{mag}>=3 \bigcirc \operatorname{mag}>=4 \bigcirc \mathrm{mag}>=5$

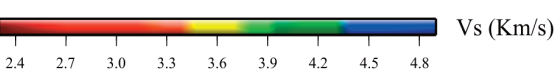

Figure 10. Different cross-sections reaching $100 \mathrm{~km}$ depth. The dark gray and the light gray graphs represent the topographic and bathymetric altitudes, respectively. Black dashed curve represents the Moho discontinuity. The yellow circles represent the seismicity beneath each section. The events were downloaded from the INGV catalogue (https://csi.rm.ingv.it/home) for a time period ranging from 06-01-1985 to 14-08-2019 and with magnitude from 3 to 6 .

values not exceeding $15 \mathrm{~km}$ depth beneath the Tyrrhenian basin but it increases and reaches depth value between 30 and $35 \mathrm{~km}$ beneath the Sicily Channel and Tunisian coast. High mantle velocity between 3.7 and $4.0 \mathrm{~km} / \mathrm{s}$ is observed also in this section, at depth between 15 and $25 \mathrm{~km}$, beneath the southern part of the Tyrrhenian basin. Other high velocity body with shear wave velocity between 4.5 and $4.8 \mathrm{~km} / \mathrm{s}$ is also shown at depth between 40 and $60 \mathrm{~km}$. Section E is crossing the Tunisian coast and the Sicily Channel. It shows a crust thickness of $25 \mathrm{~km}$ and 30 $\mathrm{km}$ beneath the Tunisian coasts and the northern part of the Sicily Channel, respectively. Section F shows a thin crust with thickness values between 18 and $20 \mathrm{~km}$ beneath the Tyrrhenian basin, and values between 30 and $35 \mathrm{~km}$ 
beneath the Sicily Channel. This section reveals also the presence of high velocity body at depths between 40 and $60 \mathrm{~km}$ beneath the Tyrrhenian basin. The seismicity plotted on this section reveals a seismic activity in the central part of the Sicily Channel and the Malta graben with some deep events at depths between 60 and $100 \mathrm{~km}$. Section $\mathrm{G}$ is parallel to the section F. This section shows a very thin crust with thickness around $15 \mathrm{~km}$ beneath the Tyrrhenian basin and reaches depths of $30 \mathrm{~km}$ beneath the Sicily Channel. High mantle values between 3.7 and 4.0 $\mathrm{km} / \mathrm{s}$ are observed beneath the southern part of the Tyrrhenian basin, lying at depth between 15 and $20 \mathrm{~km}$. We notice also the presence of the high velocity body (Vs between 4.5 and $4.8 \mathrm{~km} / \mathrm{s}$ ) beneath the Tyrrhenian basin and the island of Sicily, at depths between 40 and $60 \mathrm{~km}$. The plotted seismicity reveals a shallow activity beneath the south of the island of Sicily with some deep events reaching depth between 40 and $60 \mathrm{~km}$, beneath the central part of the island of Sicily. The section H is running along the 37th parallel north. This section crosses the southeast of the island of Sicily, the south of the Sicily Channel and reaches the Tunisian coasts. The vertical section presents a crust thickness of 30 to $35 \mathrm{~km}$ beneath Sicily and the Sicily Channel. The crust thickness becomes thinner and reaches a value of $20 \mathrm{~km}$ beneath the northeastern Tunisian coast. The seismicity reported on the section shows a crustal activity beneath the island of Sicily with some deep events reaching depths between 60 and $100 \mathrm{~km}$.

\section{Results Discussion}

In this study, we used the ambient noise tomography method to investigate the crust and uppermost mantle beneath the Sicilian channel. The tomographic maps at shorter periods (5 to 20s) reveal a negative anomalies in the southern part of the island of Sicily, the northern part of the Sicily Channel and the Tunisian margins, which is correlated with the presence of sediments at shallower depths of 5 and $10 \mathrm{~km}$ in the southern part of Sicily and in the eastern part of the Tunisian margins. These results are compatible with the Rayleigh-wave group and phase velocity tomographic maps, at the same periods, proposed by Manu-Marfo et al. [2019]. The presence of thick sediments between 5 and 15km is reported by Barberi et al. [2004]. At longer periods the phase velocity tomographic maps are sensitive to deeper structure and could provide us indications about the crust thickness changes beneath the Tunisian margin, the Sicily Channel, and the south of Sicily.

The simultaneous inversion of the group and phase velocity dispersion values allows us to map the shear wave velocity structure down to $100 \mathrm{~km}$ depth. The obtained Moho depth map (Figure 8) reports a shallow Moho beneath the southern part of the Tyrrhenian basin with depth values around $15 \mathrm{~km}$, such low values can be attributed to the extension of the south of the basin as a consequence of the retreat of the Ionian lithosphere. The Moho depth values are in agreement with the results from the recent $3 \mathrm{~d}$ shear wave velocity study of the crust and uppermost mantle beneath the Tyrrhenian basin and margins done by Manu-Marfo et al. [2019]. The Moho deepens and reaches a value of $28 \mathrm{~km}$ beneath the north-western part of the island of Sicily and the Tunisian margins. Similar depths are reported by wide angle reflection-refraction results [Cassinis et al., 2005]. The Moho deepens again and reaches an average depth value of $30 \mathrm{~km}$ beneath the central part of the Sicily Channel. Figure 8 reports also a decrease of the Moho depth values in the southern part of the channel, where it reaches a value of $24 \mathrm{~km}$. These depth values are in concordance with the NE-SW extension of the south-eastern part of the channel reported by Civile et al. [2008] and D'Agostino and Selvaggi [2004] from geological and geodetic data.

To study the resulted S-wave velocity models, we plotted 8 vertical sections mapping the crust and uppermost mantle beneath the study area. The vertical sections presented in Figure 10 with the plotted seismic events revealed very interesting features that help us to understand well the geodynamics of the Sicily Channel and its surrounding. The sections highlighted a thin crust with thickness of 15 to $20 \mathrm{~km}$ beneath the southern part of the Tyrrhenian basin (see cross sections C, D, F, and G of Figure 10) and of $20 \mathrm{~km}$ beneath Mt Etna (see section B of Figure 10). The thin crust characterizing the south of the Tyrrhenian basin, the volcanic activity of Mt. Etna and the presence of a dense crustal seismic activity in the eastern part of the island of Sicily are well correlated with the reported geodynamics of the Tyrrhenian basin, where the lithosphere is extending due to the past subduction and rollback of the Ionian slab beneath the Calabrian Arc. The obtained crustal thickness values are in agreement with those proposed by Nicolich et al. [2000], Barberi et al. [2004], Di Luccio and Pasyanos [2007] and Manu-Marfo et al. (2019). Moho depth values of $30 \mathrm{~km}$ are revealed by the sections A, B, C, D, E, F, and H (Figure 10) beneath the Sicily Channel, while lower depth values are observed in the sections A, F and $\mathrm{E}$ in the southern part of the channel. These values are comparable to the Moho depths reported by Tesauro et al. [2010] from merging the most robust and recent Moho depth maps 


\section{Radia Kherchouche et al.}

existing in the European region, and by Marone et al. [2003, 2004] from the joint inversion of local, regional and teleseismic data. The seismic activity observed in the Sicily Channel (see cross sections A, B, C, D, G and H of Figure 10) might be related to the rifting process affecting the channel and described by different authors [e.g. D'Agostino and Selvaggi, 2004; Serpelloni et al., 2007; Civile et al., 2008]. Other feature was revealed by cross sections C, D and $\mathrm{G}$, were the presence of high mantle velocity values between 3.7 and $4.0 \mathrm{~km} / \mathrm{s}$ is observed at depth between 15 and $20 \mathrm{~km}$, beneath the southern part of the Tyrrhenian basin, and at depth between 30 and $40 \mathrm{~km}$ beneath the central part of the Sicily Channel. Similar high mantle velocity values are reported by Calò et al. [2013] using tomographic inversion of regional body wave phases. This seismic velocity distribution mimics well the oceanic-continental transition in the Tyrrhenian-Sicily domain. Other important feature is represented in sections B and C (Figure 10) by the presence of high velocity body (Vs between 4.5 and $4.8 \mathrm{~km} / \mathrm{s}$ ). This finding can be interpreted as the presence of the Ionian slab subducting beneath the Calabrian Arc. Another high velocity body is observed in sections $F$ and $\mathrm{G}$ (Figure 10) with similar velocities, this feature might be interpreted as the presence of fragments of the African continental lithosphere beneath the Tyrrhenian basin.

\section{Conclusion}

Submerged by sea water, the Sicily Channel remains one of the non-well studied areas in the central Mediterranean region, due to the limited station coverage on the North African side and the lack of OBS stations on the submerged part. In our knowledge, this study is the first attempt to determine the shear wave velocity structure beneath the Sicily Channel and surrounding, with spatial resolution length of $180 \mathrm{~km}$ for structures down to $50 \mathrm{~km}$ and with a resolution length of $250 \mathrm{~km}$ for structures down to $100 \mathrm{~km}$. In this work we invert simultaneously the Rayleigh-wave group and phase velocities extracted from ambient noise and earthquake data, to determine the shear wave velocity structure down to $100 \mathrm{~km}$. The inversion results allowed us to obtain a new Moho map of the study area with a spatial resolution length of $180 \mathrm{~km}$. The Moho map reveals a shallow Moho with depth value of $15 \mathrm{~km}$ beneath the south of the Tyrrhenian basin, the depth value increases rapidly and reaches $25 \mathrm{~km}$ in the northwestern part of the island of Sicily. This Moho topography likely reflects the oceanic-continental transition in the south-eastern part of the Tyrrhenian basin. In the Sicily Channel, we observe different Moho depth values in the northern part and southern part of the channel. The average Moho depth in the northern part of the channel is about $30 \mathrm{~km}$, while it decreases and reaches a value of $25 \mathrm{~km}$ in the southern part. This is likely to be associated to the active NE-SW oriented extension reported by many authors in literature. The shear wave velocity model reveals also the presence of a high velocity body (Vs between 4.5 and $4.8 \mathrm{~km} / \mathrm{s}$ ) beneath the eastern part of the island of Sicily, this can be interpreted as the presence of the Ionian slab subducting beneath the Calabrian Arc. Other high velocity body is observed beneath the southern part of the Tyrrhenian basin and the northern and central part of the Sicily Channel, it might be interpreted as the presence of fragments of the African continental lithosphere. In conclusion, the tomography inversion of ambient noise and earthquake data allows us to provide useful informations about the seismic distribution and the Moho topography beneath the Sicily Channel and surroundings. The geometry of the crust and uppermost mantle, highlighted by this study, allowed us to have basic knowledge about the geodynamics occurring in the area that can be useful for further investigation.

Acknowledgments. R. Kherchouche acknowledges long-term support during her PhD from the ICTP-Regione Friuli Venezia Giulia earthquake programme. B. Melouk and A. Saadi acknowledge support from ICTP during their internship. We thank the anonymous reviewer for the constructive and valuable comments and Dr Ayadi and Maouche for their useful remarks. We thank the European Integrated Data Archive EIDA (http://www.orfeus-eu.org/) for facilitating the availability of continuous recording of ambient noise and earthquake data.

\section{References}

Agius, M. R., and P. Galea (2011). A single-station automated earthquake location system at Wied Dalam Station, Malta, Seismol. Res. Lett., 82(4), 545-559, doi:10.1785/gssrl.82.4.545. 
Argnani, A. (1990). The strait of Sicily rift zone: Foreland deformation related to the evolution of a back-arc basin, J. Geodyn., 12(2-4), 311-331, doi:10.1016/0264-3707(90)90028-s.

Backus, G. and F. Gilbert (1968). The Resolving Power of Gross Earth Data, Geophys. J. Int., 16(2), 169-205, doi:10.1111/j.1365-246x.1968.tb00216.x.

Barberi, G., M. T. Cosentino, A. Gervasi, I. Guerra, G. Neri, and B. Orecchio (2004). Crustal seismic tomography in the Calabrian Arc region, South Italy, Phys. Earth Planet. Inter., 147(4), 297-314, https://doi.org/10.1016/j.pepi.2004.04.005.

Bensen, G. D., M. H. Ritzwoller, M. P. Barmin, A. L. Levshin, F. Lin, M. P. Moschetti and Y. Yang (2007). Processing seismic ambient noise data to obtain reliable broad-band surface wave dispersion measurements, Geophys. J. Int., 169 (3), 1239-1260, doi:10.1111/j.1365-246x.2007.03374.x.

Bijwaard, H. and W. Spakman (2000). Non-linear global P-wave tomography by iterated linearized inversion, Geophys. J. Int., 141 (1), 71-82, https://doi.org/10.1046/j.1365-246X.2000.00053.x

Biolchi, S., G. Timothy, A. Ritienne, A. Fabrizio, S. Furlani, A. Marco and S. Devoto (2011). Late-Holocene relative sea level change in Malta, Il Quaternario, 24, 20-22.

Bonaccorso, A. and M. Mattia (2000). Deflation acting on Pantelleria Island (Sicily Channel) inferred through geodetic data, Earth Planet. Sci. Lett., 180 (1-2), 91-101, doi:10.1016/s0012-821x(00)00156-4.

Calò, M., L. Parisi and D. Luzio (2013). Lithospheric P- and S-wave velocity models of the Sicilian area using WAM tomography: procedure and assessments, Geophys. J. Int., 195, 625-649, doi:10.1093/gii/ggt252.

Calò, M., and L. Parisi (2014). Evidences of a lithospheric fault zone in the Sicily Channel continental rift (southern Italy) from instrumental seismicity data, Geophys. J. Int., 199 (1), 219-225, doi:10.1093/gii/ggu249.

Cassinis, R., S. Scarascia and A. Lozej (2005). Review of seismic Wide-Angle Reflection-Refraction (WARR) results in the Italian region (1956-1987), CROP PROJECT: Deep Seismic Exploration of the Central Mediterranean and Italy. 31-55.

Catalano, S., G. De Guidi, G. Lanzafame, C. Monaco and L. Tortorici (2009). Late Quaternary deformation on the island on Pantelleria: New constraints for the recent tectonic evolution of the Sicily Channel Rift (southern Italy), J. Geodyn., 48(2), 75-82, https://doi.org/10.1016/j.jog.2009.06.005.

Chiarabba, C., P. De Gori and F. M. Mele (2015). Recent seismicity of Italy: Active tectonics of the central Mediterranean region and seismicity rate changes after the Mw 6.3 LAAquila earthquake, Tectonophysics, 638, 82-93, doi:10.1016/j.tecto.2014.10.016.

Civile, D., E. Lodolo, L. Tortorici, G. Lanzafame and G. Brancolini (2008). Relationships between magmatism and tectonics in a continental rift: The Pantelleria Island region (Sicily Channel, Italy), Marine Geol., 251(1-2), 32-46, doi:10.1016/j.margeo.2008.01.009.

Civile, D., E. Lodolo, D. Accettella, R. Geletti, Z. Ben-Avraham, M. Deponte and R. Romeo (2010). The Pantelleria graben (Sicily Channel, Central Mediterranean): An example of intraplate "passive" rift, Tectonophysics, 490(34), 173-183, doi:10.1016/j.tecto.2010.05.008.

Civile, D., E. Lodolo, M. Zecchin, Z. Ben-Avraham, L. Baradello, D. Accettella and M. Caffau (2015). The lost Adventure Archipelago (Sicilian Channel, Mediterranean Sea): Morpho-bathymetry and Late Quaternary palaeogeographic evolution, Glob. Planet. Change, 125, 36-47, doi:10.1016/j.gloplacha.2014.12.003.

Coltelli,M., D. Cavallaro, G. D’Anna, A. D’Alessandro, F. Grassa, G. Mangano, D. Patanè and S. Gresta (2016). Exploring the submarine Graham Bank in the Sicily Channel, Ann. Geophys., 59(2), https://doi.org/10.4401/ag-6929.

Corti, G., M. Cuffaro, C. Doglioni, F. Innocenti and P. Manetti (2006). Coexisting geodynamic processes in the Sicily Channel. Postcollisional Tectonics and Magmatism in the Mediterranean Region and Asia, doi:10.1130/2006.2409(05).

Crotwell, H. P., T. J. Owens and J. Ritsema (1999). The TauP Toolkit: Flexible seismic travel-time and ray-path utilities, Seismol. Res. Lett., 70, 154-160, doi:10.1785/gssrl.70.2.154.

D’Agostino, N. and G. Selvaggi (2004). Crustal motion along the Eurasia-Nubia plate boundary in the Calabrian Arc and Sicily and active extension in the Messina Straits from GPS measurements, J. Geophys. Res.: Solid Earth, 109(B11), https://doi.org/10.1029/2004JB002998.

Devoti, R., A. Esposito, G. Pietrantonio, A. R. Pisani and F. Riguzzi (2011). Evidence of large scale deformation patterns from GPS data in the Italian subduction boundary, Earth Planet. Sci. Lett., 311(3-4), 230-241, doi:10.1016/j.epsl.2011.09.034.

Di Luccio, F. and M. E. Pasyanos (2007). Crustal and upper-mantle structure in the Eastern Mediterranean from the analysis 


\section{Radia Kherchouche et al.}

of surface wave dispersion curves, Geophys. J. Int., 169 (3), 1139-1152, doi:10.1111/j.1365-246X.2007.03332.x.

Ditmar, P.G. and T.B. Yanovskaya (1987). Generalization of the Backus-Gilbert method for Estimation of the Horizontal Variations of surface wave velocities, Izv. Phys. Solid Earth 23 (6), 470-477.

Dziewonski, A.M. and D.L. Anderson (1981). Preliminary reference Earth model, Phys. Earth Planet. Int., 25, 297-356.

Ekström, G. (2011). A global model of Love and Rayleigh surface wave dispersion and anisotropy, 25-250 s, Geophys. J. Int., 187, 3, 1668-1686, https://doi.org/10.1111/j.1365-246X.2011.05225.x.

Goldstein, P., D. Dodge, M. Firpo and Lee Minner (2003). "SAC2000”: Signal processing and analysis tools for seismologists and engineers, Invited contribution to "The IASPEI International Handbook of Earthquake and Engineering Seismology”, Edited by WHK Lee, H. Kanamori, P.C. Jennings, and C. Kisslinger, Academic Press, London.

Hansen, P.C. (1992). Analysis of discrete ill-posed problems by means of the L-curve, Society of Industrial and Applied Mathematics Review 34, 561-580.

Hansen, P.C. (1998). Rank-deficient and discrete ill-posed problems, numerical aspects of linear inversion, Society of Industrial and Applied Mathematics, Philadelphia.

Guidarelli, M., G. Stuart, J. O. S. Hammond, J. M. Kendall, A. Ayele and M. Belachew (2011). Surface wave tomography across Afar, Ethiopia: Crustal structure at a rift triple-junction zone, Geophys. Res. Lett., 38 (24), doi:10.1029/2011gl046840.

Herrmann, R. B. (2013). Computer programs in seismology: An evolving tool for instruction and research, Seismol. Res. Lett., 84, 108 -1088, doi:10.1785/0220110096.

INGC Seismological Data Center (2006). Rete sismica Nazionale (RSN), Instituto Nazionale di Geofisica e Vulcanologia (INGV), Italy. https://doi.org/10.13127/SD/XOFXNH7QFY

Lodolo, E., D. Civile, C. Zanolla and R. Geletti (2012). Magnetic signature of the Sicily Channel volcanism, Marine Geophys. Res., 33 (1), 33-44, doi:10.1007/s11001-011-9144-y.

Ludwig, W. J., J. E. Nafe and C. L. Drake (1970). Seismic refraction, in The Sea, A. E. Maxwell (Editor), 4, WileyInterscience, New York, 53-84.

Luo, Y., Y. Yang, Y. Xu, H. Xu, K. Zhao and K. Wang (2015). On the limitations of interstation distances in ambient noise tomography, Geophys. J. Int., 201, 652-661, https://doi.org/10.1093/gii/ggv043.

Marone, F., M. Van der Meijde, S. Van er Lee and D. Giardini (2003). Joint inversion of local, regional and teleseismic data for crustal thickness in the Eurasia-Africa plate boundary region, Geophys. J. Int., 154(2), 499-514, doi:10.1046/j.1365-246x.2003.01973.x.

Marone, F., S. Van der Lee and D. Giardini (2004). Three-dimensional upper-mantle S-velocity model for the EurasiaAfrica plate boundary region, Geophys. J. Int., 158 (1), 109-130, doi:10.1111/j.1365-246X.2004.02305.x.

Manu-Marfo, D., A. Aoudia, S. Pachhai and R. Kherchouche (2019). 3D shear wave velocity model of the crust and uppermost mantle beneath the Tyrrhenian basin and margins, Scientific reports; 9:3609, https://doi.org/10.1038/s41598-019-40510-z.

MedNet Project Partner Institutions. (1990). Mediterranean Very Broadband Seismographic Network (MedNet). Istituto Nazionale di Geofisica e Vulcanologia (INGV), https://doi.org/10.13127/SD/FBBBTDTD6Q.

Neri, G., C. Totaro, B. Orecchio and D. Presti (2018). What seismicity offshore Sicily suggests about lithosphere dynamics and microplate fragmentation models in the Central Mediterranean, Solid Earth Discussions, 1- 59, doi:10.5194/se-2018-112.

Nicolich, R., M. Laigle, A. Hirn, L. Cernobori, and J. Gallart (2000). Crustal structure of the Ionian margin of Sicily: Etna volcano in the frame of regional evolution, Tectonophysics, 329 (1-4), 121-139, doi:10.1016/S00401951(00)00192-X.

Okada, H. (2003). The microtremor survey method, Geophys. Monograph Series, SEG, 129.

Palano, M., L. Ferranti, C. Monaco, M. Mattia, M. Aloisi, V. Bruno and G. Siligato (2012). GPS velocity and strain fields in Sicily and southern Calabria, Italy: Updated geodetic constraints on tectonic block interaction in the central Mediterranean, J. Geophys. Res., 117, B07401, doi:10.1029/2012jb009254.

Panzera, F., S. D’Amico, G. Lombardo, P. Galea and A. Akinci (2015). Overview of the seismic hazard in the Sicily Channel archipelagos, Establishment of an Integrated Italy-Malta Cross-Border System of Civil Protection, Geophysical Aspects, 31-45, doi:10.4399/97888548825604.

Piromallo, C. and A. Morelli (2003). P wave tomography of the mantle under the Alpine-Mediterranean area, J. Geophys. Res.: Solid Earth, 108 (B2), https://doi.org/10.1029/2002JB001757. 
Rosenbaum, G. and G. S. Lister (2004). Neogene and Quaternary rollback evolution of the Tyrrhenian Sea, the Apennines, and the Sicilian Maghrebides, Tectonics, 23, (1), https://doi.org/10.1029/2003TC001518.

Ritzwoller, M. H. and A. L. Levshin (1998). Eurasian surface wave tomography: Group velocities, J. Geophys. Res.: Solid Earth, 103, (B3), 4839-4878, doi:10.1029/97jb02622.

Shapiro, N. M. and M. Campillo (2004). Emergence of broad-band Rayleigh waves from correlations of the ambient seismic noise, Geophys. Res. Lett., 31, 8-11, doi:10.1029/2004GL019491.

Shapiro, N. M., M. Campillo, L. Stehly and M. H. Ritzwoller (2005). High-resolution surface-wave tomography from ambient seismic noise, Science, 307(5715), 1615-1618, doi:10.1126/science.1108339.

Serpelloni, E., G. Vannucci, S. Pondrelli, A. Argnani, G. Casula, M. Anzidei and P. Gasperini (2007). Kinematics of the Western Africa-Eurasia plate boundary from focal mechanisms and GPS data, Geophys. J. Int., 169(3), 11801200, doi:10.1111/j.1365-246x.2007.03367.x

Spakman, W. and R. Wortel (2004). A tomographic view on western Mediterranean geodynamics. In The TRANSMED atlas. The Mediterranean region from crust to mantle, 31-52. Springer, Berlin, Heidelberg.

Spampinato, S., A. Ursino, M. S. Barbano, C. Pirrotta, S. Rapisarda, G. Larocca and P. R. Platania (2017). A Reappraisal of Seismicity and Eruptions of Pantelleria Island and the Sicily Channel (Italy), Pure Appl. Geophys., 174(7), 2475-2493, doi:10.1007/s00024-017-1550-x.

Stehly, L., M. Campillo and N. M. Shapiro (2006). A study of the seismic noise from its long-range correlation properties, J. Geophys. Res., 111(B10), doi:10.1029/2005jb004237.

Stehly, L., M. Campillo, B. Froment and R. L. Weaver (2008). Reconstructing Green's function by correlation of the coda of the correlation (C3) of ambient seismic noise, J. Geophys. Res., 113 (B11), doi:10.1029/2008jb005693.

Tesauro, M., M.K. Kaban and S. Cloetingh (2010). 3D crustal model of Western and Central Europe as a basis for modelling mantle structure, In: Cloetingh S, Negendank J (eds) New frontiers in integrated solid earth sciences. International year of planet earth. Springer, Dordrecht. Doi:10.1007/978-90-481-2737-5_2.

Vuan, A., S. D. Robertson Maurice, D. A. Wiens and G. F. Panza (2005). Crustal and upper mantle S-wave velocity structure beneath the Bransfield Strait (West Antarctica) from regional surface wave tomography, Tectonophysics, 397(3-4), 241-259, doi:10.1016/j.tecto.2004.12.011.

Wortel, M. J. R. and W. Spakman (2000). Subduction and slab detachment in the Mediterranean-Carpathian region, Science, 290(5498), 1910-1917, doi:10.1126/science.290.5498.1910.

Yanovskaya, T.B. (1997). Resolution estimation in the problems of seismic ray tomography, Izv. Phys. Solid Earth 33(9), $762-765$.

*CORRESPONDING AUTHOR: Radia KHERCHOUCHE,

Laboratoire de Géophysique, Faculté des Sciences de la Terre, de la Géographie et de l'Aménagement du territoire, and Centre de Recherche en Astronomie, Astrophysique et Géophysique, and The Abdus Salam International Centre for Theoretical Physics, Earth System Physics Section, e-mail: radia.kherchouche@gmail.com 